\title{
Nature and provenance of the sandstone used for Bayon style sculptures produced during the reign of Jayavarman VII
}

\author{
Federico Carò $^{\mathrm{a}, *}$, Janet G. Douglas ${ }^{\mathrm{b}}$ \\ ${ }^{a}$ Department of Scientific Research, The Metropolitan Museum of Art, 1000 Fifth Avenue, New York, NY 10028, United States \\ ${ }^{\mathrm{b}}$ Department of Conservation and Scientific Research, Freer Gallery of Art/Arthur M. Sackler Gallery, Smithsonian Institution, Washington, DC 20560, United States
}

\section{A R T I C L E I N F O}

\section{Article history:}

Received 13 June 2012

Accepted 16 June 2012

\section{Keywords:}

Petrography

Volcanic grains

Sandstone

Sculptures

Bayon

Angkor

Cambodia

\begin{abstract}
A B S T R A C T
Under Jayavarman VII (1182/83-ca.1218 CE) the Khmer empire reached its apex, leaving a heritage of major construction works and unique artistic production. The stone materials of several sculptures produced under his reign were characterized and compared to possible geological sources in northern and eastern Cambodia. The data suggest that a specific type of sandstone, rich in volcanic detritus, was deliberately selected and quarried from a Triassic sedimentary sequence exposed far from Angkor, the main political and economic center at that time.
\end{abstract}

(c) 2012 Elsevier Ltd. All rights reserved.

\section{Introduction}

Under the reign of Jayavarman VII (1182/83-ca.1218 CE) many significant construction projects were undertaken, such as major roads, stone bridges, hospitals and temples, which testify to a deep interaction with the local environment and knowledge of its natural resources. Simultaneously, a great number of free standing sculptures were mass-produced and installed in sanctuaries throughout the empire which encompassed, besides present-day Cambodia, parts of Thailand, Laos and Vietnam (Cœdès, 1958; Stern, 1965; Woodward, 1994/95). Several likenesses of the king and members of his family rendered in stone are known, together with numerous images of Buddhist and Hindu deities in the socalled Bayon style (Cœdès, 1958; Stern, 1965; Jessup and Zephir, 1997).

Recent studies using petrography suggest the existence of a specific royal workshop active during the reign of Jayavarman VII which has been characterized, besides by distinctive style and iconography, by a specific type of stone material (Douglas and Sorensen, 2007). The identified stone is an immature sandstone containing significant amounts of microlithic volcanic lithic fragments, albitized feldspar grains, and amphibole.

\footnotetext{
* Corresponding author. Tel.: +1 212396 5353; fax: +1 2123965466.

E-mail address: federico.caro@metmuseum.org (F. Carò).
}

The provenance of this sandstone and the location of the workshop have been the subject of much speculation. Some scholars have placed the source of stone used for both architecture and sculpture of Bayon style in Phnom Kulen (Kulen Mountains), or more generically among the sandstones belonging to the Khorat series (Delvert, 1963; Woodward, 1980; Jessup and Zephir, 1997). If this hypothesis is true for the stone material used for temples construction under Jayavarman VII (Uchida et al., 2007; Kučera et al., 2008), evidence suggests that the sandstone selected for free standing sculptures does not belong to the Jurassic-Cretaceous formations exposed at Phnom Kulen (Terrain Rouge and Gres Superieurs Formations) or to any of those formations traditionally included in the Khorat Group (Contri, 1972; Fleuriot de Langle, 1973; United Nations, 1993; Racey et al., 1996; Sotham, 1997; Carò and $\mathrm{Im}, 2012$ ).

The current study is focused on a Triassic sedimentary formation as the potential source of such sandstone. In particular, the study aims at: 1) characterizing the stone belonging to the Triassic formation in a selected area of Cambodia and verifying the existence of remains of quarrying activity; 2) characterizing the stone materials of an enlarged corpus of Bayon style sculptures; 3 ) determining whether the stone in vogue under Jayavarman VII originated from the Triassic formation.

Given the vast exposure of Triassic sedimentary rocks in Cambodia, pilot sites must be selected among several that could have been potentially a source of stone material. The surveyed areas 
in this study have thus been chosen either because geological evidence points to lithotypes similar to those described in previous studies (Contri, 1972; Douglas and Sorensen, 2007; Carò, 2009; Douglas et al., 2010), or because ancient quarries have been previously documented in these areas.

\section{Materials and methods}

\subsection{The studied sculptures}

The corpus of sculptures includes 57 free-standing figures and steles of Bayon style from the Dépôt de la Conservation d'Angkor (DCA), Siem Reap (42 objects), the National Museum of Cambodia (NMC) (12), The Metropolitan Museum of Art (MMA) (2), and the Arthur M. Sackler Gallery of Art at the Smithsonian Institution (AMSG) (1). The studied objects represent a wide variety of Buddhist as well as Vişnuite and Sivaite iconographies of Bayon style and include, in order of abundance, images of Avalokiteśvara/ Lokeśvara (11), Vişnu (8), Buddha (6), portrait of king Jayavarman VII (4), Śiva (3), Prajñāpāramitā (2), Hevajra (1), Lakşhmīì (1), a series of unidentified male (9) and female (8) figures, and pillar steles with inscriptions (4).

Most of the sculptures are well-provenanced and originate from the Angkor region (36), but also from other sites in Siem Reap province, such as Roluos (3) and Kralanh (1), and other provinces, such as Banteay Meanchey (4), and Preah Vihear (3). Ten objects are of uncertain or unknown provenance. The complete list of objects, including their description, accession number, and provenance is presented in Table 1. Because of the great number of the studied sculptures, only few representative examples are presented in Fig. 1.

\subsection{The surveyed areas}

The surveyed areas are located in the provinces of Preah Vihear and Kratie, and are included in the 1:200,000 sheets Tbeng Meanchey and Mondulukiri published by the Department of Geology, General Department of Mineral Resources of Cambodia and based on the reconnaissance mapping carried out in 1967/78 by the French Bureau de Recherches Geologiques et Minières (Fig. 2) (Contri, 1972; Fleuriot de Langle, 1973). Natural sandstone outcrops, documented quarries and undocumented traces of quarrying activity on sandstone outcrops have been surveyed and sampled.

In Preah Vihear province, the studied sites are located in the districts of Sangkom Thmai and Rovieng. These sites are distributed in the surroundings of the temple of Preah Khan of Kompong Svay (also known as Bakan) and in the area comprised between the villages of Ta Sang and Svay Damnak, a well-known center of iron mining and smelting since ancient times (Jacques, 2007). The landscape is characterized by flat terraces of Lower Quaternary sediments incised by an intricate network of seasonal streams constituting the drainage system of the Stoung River. These sediments are discontinuously but intensively laterized and rich in iron pisolites. Given the reduced thickness of the Quaternary deposits, the Triassic substratum is often exposed in riverbeds and more rarely in extended terraces, in form of massive, almost structureless sandstone boulders separated by a system of orthogonal fractures, and fine-grained, laminated and nodular mudstones interbeds.

Five major sites have been surveyed around Preah Khan of Kompong Svay. The first is located southwest of the temple, in the riverbed of the Angkrông Creek $\left(13^{\circ} 21^{\prime} 32.16^{\prime \prime} \mathrm{N}\right.$ and $104^{\circ} 40^{\prime} 36.00^{\prime \prime} \mathrm{E}$ ), where a vast outcrop of Lower and Middle Triassic sandstone has been mapped (Contri, 1972).

The last four sites are located along or in the riverbed of Stoung River, in the stretch that runs east of the temple's baray, and situated between $13^{\circ} 26^{\prime} 44.20^{\prime \prime} \mathrm{N}-104^{\circ} 46^{\prime} 13.40^{\prime \prime} \mathrm{E}$ and $13^{\circ} 24^{\prime} 26.16^{\prime \prime} \mathrm{N}-104^{\circ} 47^{\prime} 41.40^{\prime \prime} \mathrm{E}$. The majority of the samples originated from natural outcrops, as only few traces of aligned wedge holes, indicating possible stone quarrying, have been documented in this area (sample 3599).

Numerous sites have been surveyed north of the village of Svay Damnak. In this area, vast outcrops of Triassic rocks are mapped in the 1:200,000 sheet of Tbeng Meanchey and described by J. P. Contri in the relative explanatory notes (Contri, 1972). Interestingly, Contri mentions in his geological report the similarity between these lithotypes and the sculptures located at that time in the temple of Preah Khan of Kompong Svay. Triassic sandstone is exposed in massive boulders north of Svay Damnak, and forms the plateaus of Phnom Krang Aung and Phnom Chang Han southeast of the village. Sandstone outcrops have been sampled along and in riverbeds in an area of about $20 \mathrm{~km}^{2}$. Besides isolated, scattered outcrops, three main sites have been studied. The first two are locally known as Andong Young and Trapeang Khong, and are located in and around the riverbed of a tributary of Stoūng River. These two sites bear clear traces of quarrying in form of wedge holes and split boulders (Fig. 3). These traces are concentrated in a limited portion of the site, and masked by abundant sediment. The third site is a vast sandstone terrace $1 \mathrm{~km}$ south of Trapeang Khong with no evidence of quarrying activity.

In Kratie province, the studied quarries are located in the district of Kratie, and are known under the names of Thmei Sandan and Trapeang Tuol Kruos (Bruguier, 2006). Recent detailed stratigraphic studies in Sre Sbov, a village about $24 \mathrm{~km}$ north Thmei Sandan and Trapeang Tuol Kruos, show that Quaternary deposits are 1-2 m thick and uncomformably overlie the Triassic Indosinian sandstone (Demeter et al., 2010).

Thmei Sandan is located $2.6 \mathrm{~km}$ east of the Mekong River, $0.5 \mathrm{~km}$ northeast of the road between Kratie and Stoeng Treng. Here, several pits and channels are scattered around the main outcrop body, and massive dressed blocks of sandstone were left abandoned in the field (Fig. 4). Similar dressed blocks of sandstones can be seen half buried in the village of Sandan, about $1 \mathrm{~km}$ south of the quarry.

The quarry of Trapeang Tuol Kruos is located $12 \mathrm{~km}$ east of the Mekong, $4 \mathrm{~km}$ northeast the remains of Prasat Pram. This site is smaller than Thmei Sandan and consists of a few basins where sandstone boulders, sometimes showing chisel marks, are exposed. A massive squared block, partially dressed in form of a pedestal, is abandoned in the field (Fig. 4).

\subsection{Analytical method}

Polished thin sections were prepared from sandstone fragments embedded in epoxy resin. For each sample, at least 300 detrital grains were counted and each grain classified and measured by means of a micrometric eyepiece using a Nikon Eclipse E600 polarized light microscope. Detrital minerals have been further characterized by scanning electron microscopy and energy dispersive $\mathrm{x}$-ray spectroscopy (Philips XL30 W/TMP Series electron microscope equipped with an EDAX ECON4 Si(Li) EDS detector and LEO 1455VP electron microscope with Link Pentafet Si(Li) SATW EDS detector).

Samples were analyzed by electron probe microanalysis (EMPA) in spot mode on the JEOL JXA-8900R microprobe in the Smithsonian's Department of Mineral Sciences, National Museum of Natural History. Analyses were obtained at a $15 \mathrm{kV}$ acceleration voltage, a sample current of $\sim 0.025 \mu \mathrm{A}$, a counting time of $20 \mathrm{~s}$ for each element, and corrected for ZAF. Standards were a combination of silicate and oxide standards calibrated by wet chemical analysis (Jarosewich et al., 1980). 
Table 1

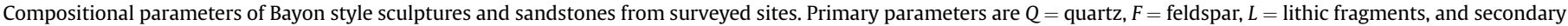
parameters are $L_{\mathrm{v}} / L=$ volcanic lithics over total lithics, mean grain size, and sorting.

\begin{tabular}{|c|c|c|c|c|c|c|c|c|c|}
\hline Sample $n^{\circ}$ & Inventory $\mathrm{n}^{\circ}$ & Description & Provenance & $\mathrm{Q}(\%)$ & $\mathrm{F}(\%)$ & $\mathrm{L}(\%)$ & $L_{\mathrm{V}} / \mathrm{L}$ & $\begin{array}{l}\text { Mean grain } \\
\text { size }(\mathrm{mm})\end{array}$ & Sorting $(\sigma)$ \\
\hline NMC54 & K54 & Male, head & Angkor area & 17.2 & 48.4 & 34.4 & 0.83 & 0.17 & 0.61 \\
\hline NMC139 & K139 & Avalokiteśvara/Lokeśvara & Ta Phrom & 16.2 & 38.7 & 45.1 & 0.95 & 0.20 & 0.62 \\
\hline NMC702 & K702 & Avalokiteśvara/Lokeśvara & Unknown & 14.1 & 36.1 & 49.8 & 0.94 & 0.20 & 0.66 \\
\hline NMC935 & K935 & Buddha & Angkor Thom & 21.6 & 39.4 & 39.0 & 0.91 & 0.19 & 0.71 \\
\hline NMC990 & K990 & Avalokiteśvara/Lokeśvara & Angkor Thom, Tep Pranam & 43.6 & 51.9 & 4.5 & 0.91 & 0.20 & 0.99 \\
\hline NMC1695 & K1695 & Avalokiteśvara/Lokeśvara & Angkor Thom & 21.9 & 34.6 & 43.5 & 0.88 & 0.21 & 0.76 \\
\hline NMC1703 & K1703 & Jayavarman VII & Krol Romeas & 15.2 & 40.7 & 44.0 & 0.94 & 0.16 & 0.63 \\
\hline NMC1725 & K1725 & Lakşhmmī & $\begin{array}{l}\text { Banteay Chhmar } \\
\text { Banteay Torp }\end{array}$ & 12.9 & 47.4 & 39.8 & 0.92 & 0.18 & 0.65 \\
\hline NMC2770 & K2770 & Jayavarman VII & Preah Khan of Kompong Svay & 13.3 & 42.8 & 43.9 & 0.90 & 0.18 & 0.63 \\
\hline NMC2851 & K2851 & Jayavarman VII & Preah Khan of Kompong Svay & 9.0 & 46.5 & 44.4 & 0.94 & 0.19 & 0.67 \\
\hline NMC2995 & K2995 & Vişnu & Angkor Wat & 25.2 & 52.8 & 22.0 & 0.63 & 0.18 & 0.71 \\
\hline NMC3089 & K3089 & Jayavarman VII & Krol Romeas & 22.1 & 40.7 & 37.2 & 0.85 & 0.20 & 0.65 \\
\hline МMА36.96.4 & 36.96 .4 & Hevajra & Angkor Thom & 22.9 & 48.2 & 28.9 & 0.89 & 0.18 & 0.71 \\
\hline MMA02.477 & 2002.477 & Avalokiteśvara/Lokeśvara & Unknown & 19.5 & 47.4 & 33.2 & 0.94 & 0.16 & 0.63 \\
\hline AMSG1987.910 & S1987.910 & Avalokiteśvara/Lokeśvara & Unknown & 11.7 & 34.8 & 53.5 & 0.88 & 0.21 & 0.74 \\
\hline DCA1 & 1195 & Avalokiteśvara/Lokeśvara & Unknown & 12.0 & 37.3 & 50.7 & 0.86 & 0.24 & 0.68 \\
\hline DCA2 & $5742 / 1050$ & Vişnu & Phnom Dei & 11.8 & 43.1 & 45.0 & 0.95 & 0.20 & 0.72 \\
\hline DCA3 & 5740 & Vişnu & Phnom Dei & 11.4 & 42.2 & 46.5 & 0.91 & 0.21 & 0.65 \\
\hline DCA4 & 5739 & Avalokiteśvara/Lokeśvara & Daun Tei & 11.1 & 45.3 & 43.6 & 0.98 & 0.19 & 0.69 \\
\hline DCA5 & $5741 / 1022$ & Avalokiteśvara/Lokeśvara & Phnom Dei & 19.2 & 41.0 & 39.7 & 0.97 & 0.19 & 0.60 \\
\hline DCA6 & 5743 & Śiva & Phnom Dei & 13.8 & 37.7 & 48.5 & 0.92 & 0.19 & 0.60 \\
\hline DCA7 & 930 & Prajńāpāramitā & Unknown & 23.4 & 31.5 & 45.2 & 0.83 & 0.22 & 0.71 \\
\hline DCA8 & - & Male, bust & Ta Prohm & 43.6 & 48.8 & 7.6 & 0.77 & 0.14 & 0.60 \\
\hline DCA9 & 486 & Buddha & Prasat Ta Nei & 14.5 & 45.1 & 40.4 & 0.87 & 0.19 & 0.67 \\
\hline DCA10 & 488 & Buddha & Prasat Ta Nei & 14.6 & 46.5 & 38.9 & 0.93 & 0.24 & 0.67 \\
\hline DCA11 & 491 & Buddha & Prasat Ta Nei & 16.2 & 46.6 & 37.3 & 0.92 & 0.20 & 0.63 \\
\hline DCA12 & $4152 / 42$ & Buddha & Unknown & 35.1 & 60.3 & 4.6 & 0.27 & 0.19 & 0.91 \\
\hline DCA13 & 675 & Vişnu & Kok Pei, Phnom Krom & 19.9 & 36.0 & 44.1 & 0.68 & 0.27 & 0.84 \\
\hline DCA14 & 35 & Buddha & Angkor Thom & 9.6 & 41.7 & 48.7 & 0.93 & 0.18 & 0.65 \\
\hline DCA15 & 1200 & Stele & Banteay Chhmar & 12.7 & 36.3 & 50.9 & 0.92 & 0.18 & 0.77 \\
\hline DCA16 & 1131 & Stele & Banteay Chhmar & 14.9 & 42.3 & 42.9 & 0.89 & 0.20 & 0.59 \\
\hline DCA17 & 570 & Stele & Preah Khan, Siem Reap & 35.1 & 36.6 & 28.2 & 0.54 & 0.28 & 0.80 \\
\hline DCA19 & - & Stele & Banteay Chhmar & 13.3 & 38.1 & 48.6 & 0.95 & 0.20 & 0.59 \\
\hline DCA20 & $3368 / 93$ & Male, standing & Angkor Thom & 21.9 & 42.9 & 35.2 & 0.83 & 0.16 & 0.57 \\
\hline DCA21 & 51 & Vişnu & Trapeang Pong, Roluos & 9.6 & 40.6 & 49.8 & 0.87 & 0.21 & 0.62 \\
\hline DCA22 & $5421 / 126$ & Female, standing & Takeo & 13.1 & 34.3 & 52.5 & 0.88 & 0.19 & 0.56 \\
\hline DCA23 & $4629 / 306$ & Vișņu & Bakong, Roluos & 12.0 & 39.6 & 48.4 & 0.92 & 0.19 & 0.66 \\
\hline DCA24 & $6827 / 307$ & Vişnu & Prasat Suor Prat & 11.6 & 44.9 & 43.5 & 0.96 & 0.17 & 0.61 \\
\hline DCA25 & $541 \mathrm{~A} / 248$ & Male, standing & Prasat Suor Prat & 15.9 & 34.9 & 49.2 & 0.92 & 0.22 & 0.67 \\
\hline DCA26 & $2720 / 186$ & Avalokiteśvara/Lokeśvara & Prah Ko, Roluos & 11.8 & 46.0 & 42.2 & 0.93 & 0.21 & 0.62 \\
\hline DCA27 & $6829 / 60$ & Śiva & Prasat Suor Prat & 14.0 & 43.3 & 42.8 & 0.95 & 0.21 & 0.61 \\
\hline DCA28 & $1444 / 109$ & Male, standing & Prasat Bay Kaek & 14.0 & 42.7 & 43.4 & 0.89 & 0.22 & 0.62 \\
\hline DCA29 & $6770 / 253$ & Male, standing & Takeo & 12.0 & 49.8 & 38.2 & 0.92 & 0.16 & 0.62 \\
\hline DCA30 & 107 & Male, standing & Unknown & 16.1 & 40.2 & 43.8 & 0.88 & 0.20 & 0.63 \\
\hline DCA31 & 260 & Male, bust & Takeo & 15.5 & 41.2 & 43.4 & 0.92 & 0.20 & 0.72 \\
\hline DCA32 & $6353 / 174$ & Prajńāpāramitā & Unknown & 13.7 & 48.1 & 38.3 & 0.96 & 0.17 & 0.62 \\
\hline DCA33 & $1118 / 185$ & Avalokiteśvara/Lokeśvara & Angkor, Western Baray & 10.5 & 28.1 & 61.4 & 0.94 & 0.22 & 0.69 \\
\hline DCA34 & 4658 & Vişņu & Banteay Kdei & 8.7 & 35.9 & 55.4 & 0.93 & 0.24 & 0.65 \\
\hline DCA35 & $4652 / 862$ & Female, standing & Banteay Kdei & 13.7 & 44.3 & 42.0 & 0.94 & 0.15 & 0.57 \\
\hline DCA36 & $6750 / 870$ & Female, standing & Prasat Ta Nei & 15.8 & 43.3 & 40.9 & 0.92 & 0.24 & 0.70 \\
\hline DCA37 & $4228 / 864$ & Female, standing & Angkor Thom & 15.6 & 35.3 & 49.1 & 0.94 & 0.19 & 0.67 \\
\hline DCA38 & $6749 / 782$ & Female, standing & Prasat Ta Nei & 23.9 & 58.7 & 17.4 & 0.63 & 0.22 & 0.83 \\
\hline DCA39 & $753 / 762$ & Male, standing & Unknown & 17.6 & 44.6 & 37.8 & 0.93 & 0.19 & 0.74 \\
\hline DCA41 & $6300 / 698$ & Female, standing & Prasat Kuk Snuol & 20.9 & 71.3 & 7.8 & 0.89 & 0.08 & 0.66 \\
\hline DCA42 & $1464 / 793$ & Female, standing & Ta Prohm & 19.2 & 33.2 & 47.6 & 0.88 & 0.23 & 0.68 \\
\hline DCA43 & 1711 & Female, standing & Unknown & 11.8 & 45.4 & 42.8 & 1.00 & 0.13 & 0.66 \\
\hline DCA44 & $237 \mathrm{~B} / 370$ & Śiva & Ta Prohm & 10.5 & 43.4 & 46.1 & 0.90 & 0.20 & 0.67 \\
\hline $136 \mathrm{~B}$ & - & Quarry & Thmei Sandan, Kratie & 47.0 & 45.3 & 7.6 & 0.28 & 0.22 & 0.92 \\
\hline 141 & - & Quarry & Trapeang Tuol Kruosm, Kratie & 50.0 & 24.5 & 25.5 & 0.31 & 0.13 & 0.84 \\
\hline 125 & - & Outcrop & Stoung, East of Preah Khan Kompong Svay & 37.4 & 48.3 & 14.3 & 0.17 & 0.15 & 0.89 \\
\hline 254 & - & Outcrop & Stoung, East of Preah Khan Kompong Svay & 17.8 & 56.6 & 25.6 & 0.66 & 0.27 & 0.84 \\
\hline 3599 & - & $\begin{array}{l}\text { Outcrop with traces } \\
\text { of quarrying }\end{array}$ & Stoung, East of Preah Khan Kompong Svay & 38.9 & 54.4 & 6.7 & 0.08 & 0.11 & 0.82 \\
\hline 264 & - & Outcrop & Angkrong, West of Preah Khan Kompong Svay & 39.3 & 40.6 & 20.1 & 0.78 & 0.27 & 0.78 \\
\hline 265 & - & $\begin{array}{l}\text { Outcrop with traces } \\
\text { of quarrying }\end{array}$ & Angkrong, West of Preah Khan Kompong Svay & 34.5 & 41.0 & 24.5 & 0.88 & 0.25 & 0.77 \\
\hline 179 & - & Outcrop & Trapeang Khong, Svay Damnak & 11.6 & 43.1 & 45.3 & 0.90 & 0.19 & 0.60 \\
\hline 184 & - & $\begin{array}{l}\text { Outcrop with traces } \\
\text { of quarrying }\end{array}$ & Trapeang Khong, Svay Damnak & 26.3 & 50.0 & 23.7 & 0.71 & 0.23 & 0.83 \\
\hline 191 & - & Outcrop & Trapeang Khong, Svay Damnak & 24.5 & 49.8 & 25.7 & 0.46 & 0.24 & 0.77 \\
\hline
\end{tabular}


Table 1 (continued)

\begin{tabular}{|c|c|c|c|c|c|c|c|c|c|}
\hline Sample $\mathrm{n}^{\circ}$ & Inventory $\mathrm{n}^{\circ}$ & Description & Provenance & $\mathrm{Q}(\%)$ & $\mathrm{F}(\%)$ & $\mathrm{L}(\%)$ & $L_{\mathrm{V}} / \mathrm{L}$ & $\begin{array}{l}\text { Mean grain } \\
\text { size }(\mathrm{mm})\end{array}$ & Sorting $(\sigma)$ \\
\hline 239 & - & Outcrop & South of Trapeang Khong & 38.5 & 56.7 & 4.8 & 0.40 & 0.14 & 0.88 \\
\hline 161 & - & $\begin{array}{l}\text { Outcrop with traces } \\
\text { of quarrying }\end{array}$ & Andong Young, Svay Damnak & 17.0 & 58.0 & 25.0 & 0.64 & 0.22 & 0.78 \\
\hline 162 & - & $\begin{array}{l}\text { Outcrop with traces } \\
\text { of quarrying }\end{array}$ & Andong Young, Svay Damnak & 27.5 & 53.4 & 19.1 & 0.56 & 0.20 & 0.82 \\
\hline 202 & - & $\begin{array}{l}\text { Outcrop with traces } \\
\text { of quarrying }\end{array}$ & Andong Young, Svay Damnak & 26.8 & 55.0 & 18.2 & 0.50 & 0.20 & 0.75 \\
\hline 210 & - & Outcrop & Andong Young, Svay Damnak & 22.8 & 51.2 & 26.0 & 0.52 & 0.23 & 0.80 \\
\hline 214 & - & Outcrop & Andong Young, Svay Damnak & 24.1 & 45.5 & 30.4 & 0.65 & 0.23 & 0.80 \\
\hline 164 & - & Outcrop & North of Svay Damnak & 23.5 & 50.7 & 25.8 & 0.50 & 0.21 & 0.92 \\
\hline
\end{tabular}

Note: NMC = National Museum of Cambodia, MMA = The Metropolitan Museum of Art, AMSG = Arthur M. Sackler Gallery, DCA = Dépôt de la Conservation d'Angkor.

\section{Results}

\subsection{Geology of the Triassic formation}

In this study, the attention is focused on a complex sedimentary sequence of Triassic age, which is exposed in a vast area of presentday Cambodia stretching east from Preah Vihear province to the border with Vietnam, and in scattered outcrops in the provinces of Kompong Speu and Takeo. Fig. 2 schematically presents the distribution of the outcrop of Triassic age, as well as JurassicCretaceous sedimentary units in the considered area.

North of the plateau of Kompong Cham, in between the provinces of Preah Vihear and Kompong Thom, a vast Triassic peneplain develops with variable altitude and heterogeneous character towards the east and the regions of Kratie and Mondulkiri (Carling, 2009). This formation is known in Thailand as Huai Hin Lat Formation (Racey et al., 1996), while in Cambodia does not have a conventionally recognized name. Here it is referred to simply as the "Triassic formation".

Throughout the considered area, the outcrops are discontinuous and highly leveled through weathering. Generally, Quaternary loosely consolidated sand deposits of variable thickness unconformably overlie the Triassic substratum (Alabouvette, 1973). The Triassic formation is best exposed in minor and major riverbeds, such as the secondary branches of the Mekong River in Kratie province, where it forms numerous braided rapids. Some Triassic outcrops in the Mekong River bear traces of inscriptions or chisel marks, such as in Thmâ Krae, or Koh Sam Thom.

Because of its scattered dispersion and variable attitude, it is almost impossible to describe and detail the Triassic sedimentary sequence. The available data, consisting in reconnaissance mapping and sample petrography carried out by J. P. Contri and P. Fleuriot de Langle of the Bureau de Recherches Geologiques et Miniere during the years 1966-1970, do not delineate the relationships among the various facies to allow the reconstruction of the stratigraphic column and structural asset of such heterogeneous detrital sequence. However, the French geologists provide indispensable description to construct a basic overview of the most common sedimentary facies and that, in some occasions, are quite detailed even at the outcrop scale.

Field observations clearly indicate that the Triassic formation has been folded and tilted, possibly during the final stages of the Indosinian Orogeny (Metcalfe, 1994; Carter et al., 2001), resulting in variable strike direction and dip of the outcrops throughout the country (Fleuriot de Langle, 1973). In the considered area there is a general tendency for the sequence to crop out striking in the NNE-SSW direction and with an E-SE dip ranging from 30 to $90^{\circ}$.

In central eastern Cambodia, the undifferentiated Triassic sequence is considered to be mostly of marine origin, and correlated by French geologists to the well documented marine succession of Rovieng (early-middle Triassic, Alabouvette, 1973).
Geologists seem to agree that two main facies constitute this Triassic sedimentary sequence: 1 . a lower level characterized by mudstone, mostly shales and marls, with subordinate arkosic sandstone interbeds; 2 . an upper level characterized by massive sandstone, microbreccias and breccias of variable texture and composition, with occasional marl interbeds.

Several mudstone facies belonging to the lower level are described in the geological explanatory notes by Contri (1972) and Fleuriot de Langle (1973), but no clear understanding of their mutual relationship at the large scale is given. Herein are reported the most common characteristics of this series, as a more detail analysis is beyond the scope of this paper. These fine-grained sediments are usually compact, laminated and with high degree of fissility. Often, they contain irregularly shaped nodules, which are more evident in the weathered rock. The color varies according to the mineralogy and the organic matter from pale gray-yellow to brown, to dark gray and black. Their composition is variable from markedly siliceous shale to calcareous mudstone where the clay fraction is $<20 \%$. Content of organic matter and fossils widely varies as well, and includes sterile and fossiliferous horizons, typical of Triassic marine environments (Contri, 1972; Fleuriot de Langle, 1973).

Immature sandstone of average arkosic composition is intercalated to thinly bedded mudstones. These sandstones are generally massive and compacted, with angular to sub-rounded grains of predominant quartz, feldspars and subordinate lithic fragments, in siliceous and calcareous cement. Fieldwork suggests that texture and composition are quite variable, ranging from feldspathic to litho-feldspathic arenite, depending on the abundance of lithic fragments, and either fine- or coarse-grained. Given the scattered information of such a widely exposed heterogeneous formation, any attempt to describe its general characters should be carefully pondered. However, by merging recent direct field observations and the existing geological bibliography, it is possible to recognize some distinguishing features that characterize these sandstones, namely: the massive structure with little or no apparent bedding, the immature character expressed by poor sorting and angularity of the framework grains, and the ubiquitous, though variable, presence of lithic fragments derived from low-grade metamorphic rocks (phyllite), and microlithic to aphanitic intermediate volcanic rocks.

Sandstones, microbreccia and breccias of heterogeneous composition become dominant towards the upper level of the Triassic sequence. These sediments rework DevonianCarboniferous shale and schist, Permian limestone and andesite, and are generally immature and rich in lithic fragments. These terms crop out with common characteristics in an ample area between the provinces of Kompong Thom and Preah Vihear and extend at shallow depth towards the Mekong River, where emerge in scattered outcrops in the provinces of Stung Treng, Kratie and Kompong Cham, and more extensively, in vast areas of Mondulkiri 

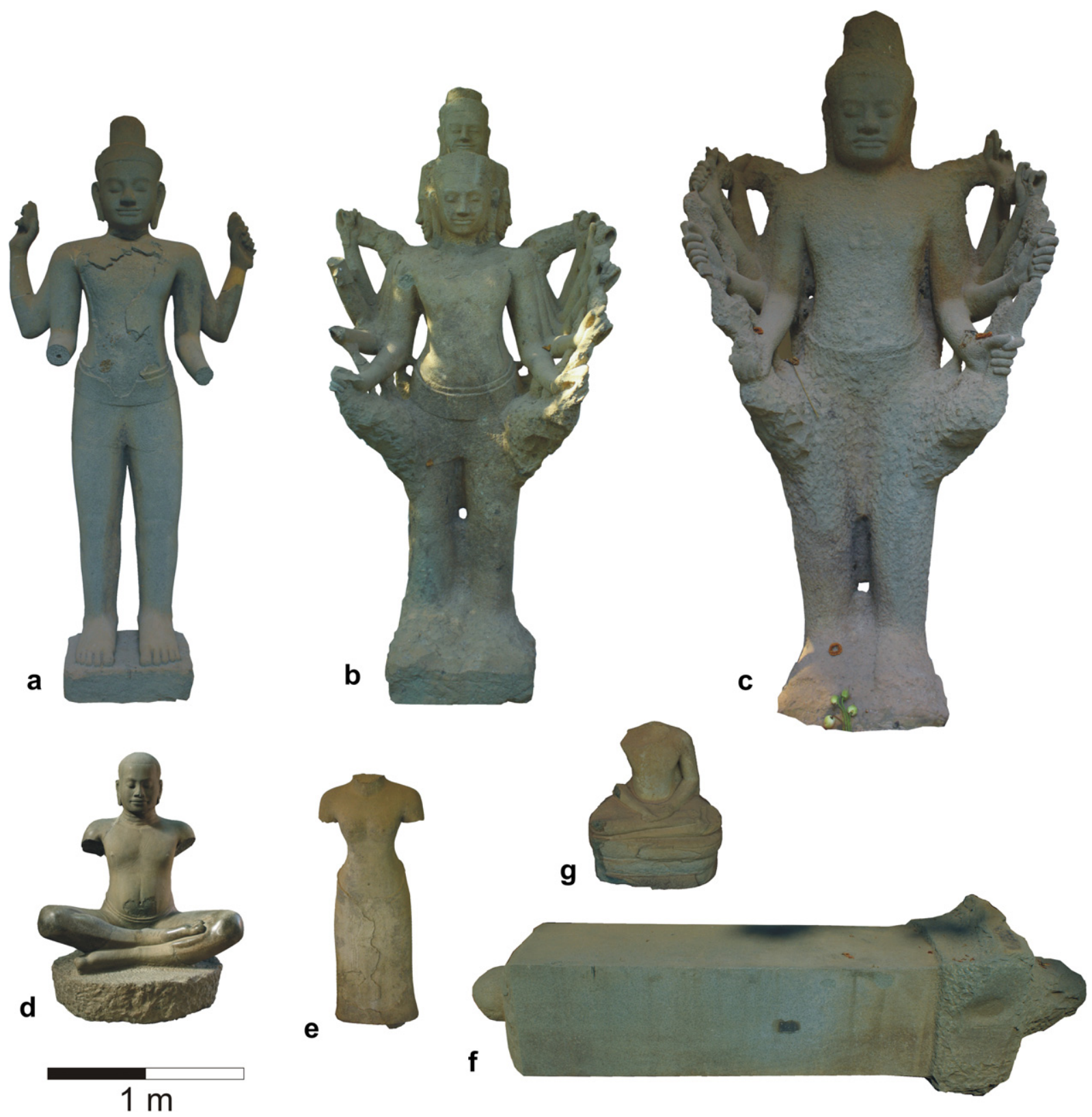

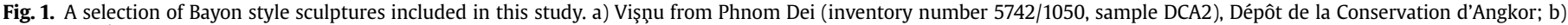

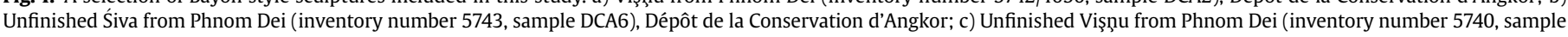

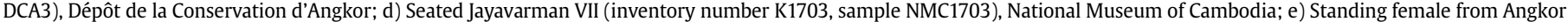

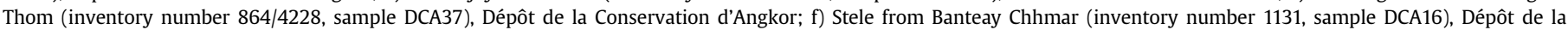

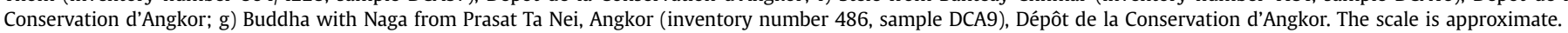

province, where is however included in the undifferentiated Triassic sequence.

Macroscopically, these terrigenous sandstones are greenish- to bluish-gray in color, speckled with coarse white feldspar and dark lithic grains, and show little evidence of internal structures. Oversized angular to sub-rounded clasts (black laminated shale or other lithic fragments of both volcanic and metamorphic nature) are suspended in the sandy matrix, suggesting a possible turbidity current deposit.

Compositionally, they are characterized by abundant feldspars, occasionally albitized and/or replaced by authigenic calcite, and by a lithic fraction dominated by a mixture of volcanic and low-grade metamorphic parent rocks. The abundance and relative proportion of these lithic fragments vary widely, with volcanic lithic fragments being more common in the finer lithotypes of the northwestern sector. In some cases, such as the outcrops located between Kompong Thom and Preah Vihear provinces or in northeast and southwest Kratie province, intermediate microlithic and vitreous volcanic lithic fragments with amphibole with green pleochroism dominate the framework grains and constitute the fine matrix of this immature sandstone, indicating a nearby, relatively young, and unaltered andesitic source (Contri, 1972; Douglas and Sorensen, 2007).

During their fieldwork in the late 1960s, French geologists noticed for the first time the macroscopic similarity of the outcropping sandstone to the stone of Bayon style sculptures found in the temple of Preah Khan of Kompong Svay (Contri, 1972). 


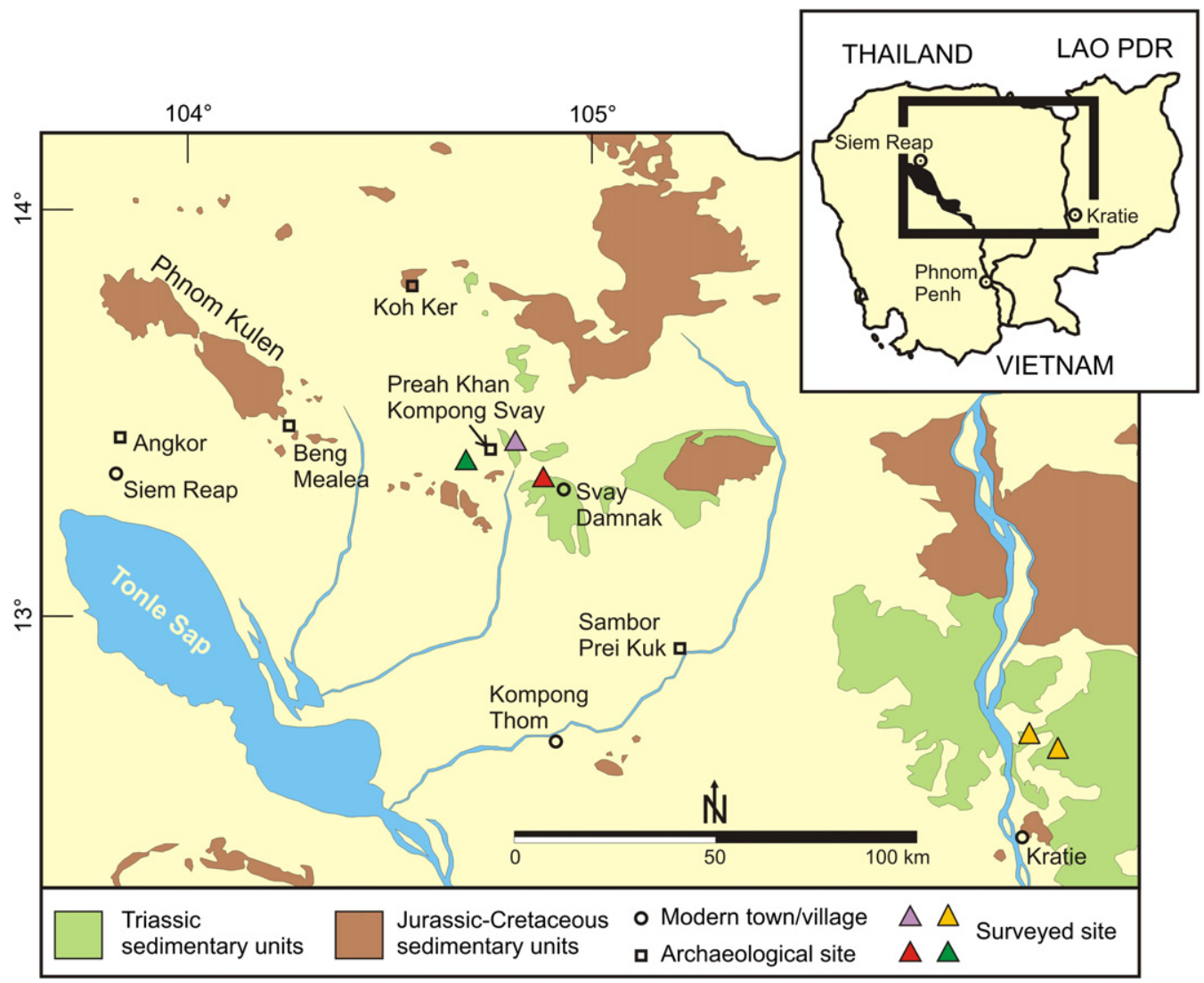

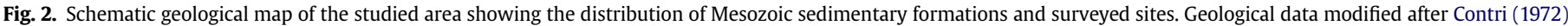
and Fleuriot de Langle (1973).

Examples of the interaction between andesitic flows, which are abundantly documented in this area, and Triassic sedimentary rocks can be seen around Phnom Klek Klak, a diorite massif located about $40 \mathrm{~km}$ northeast of the town of Kratie (Fleuriot de Langle, 1973). Immature sandstones and microbreccias rich in andesite, shale and phyllite fragments and abundant authigenic calcite are exposed also northeast of Memot, along the National Highway 7.
Less detailed is the available information about the Triassic sequence between the Mekong River and the Vietnam border. Despite that the formation covers vast areas of Mondolkiri province, or probably because of this, most of the outcrops are grouped together as "undifferentiated Triassic", and little is known about the characteristics of the series. The lithotypes show similarities with the Triassic sequence previously described, and include breccia,
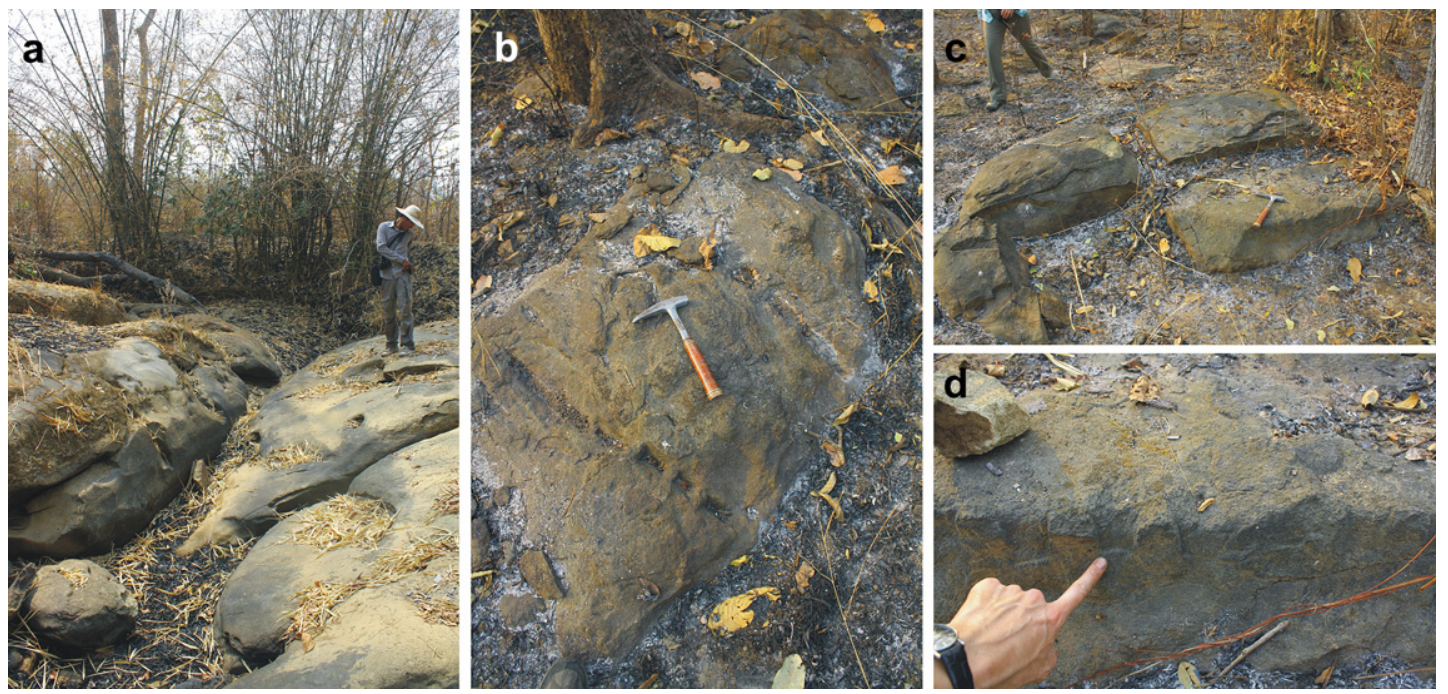

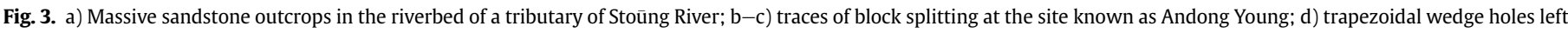
on a split boulder at the site of Trapeang Khong. All these sites are located northwest of Svay Damnak. 

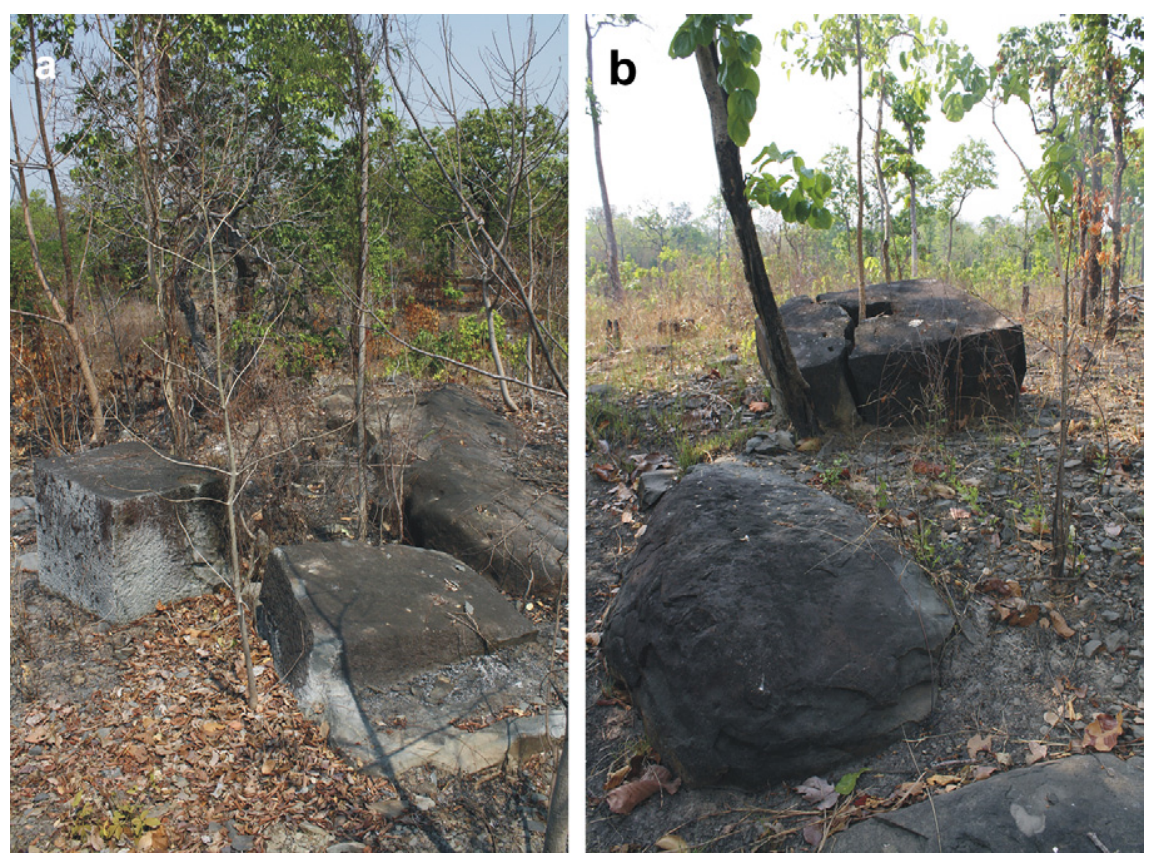

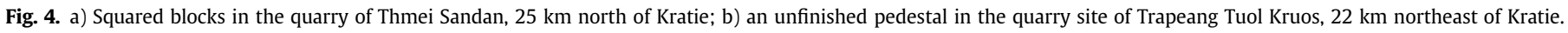

microbreccia and sandstone similar to those described above, occasionally with mudstones interbeds (Fleuriot de Langle, 1973).

\subsection{Petrography of the studied samples}

The majority of studied field and sculpture samples (95\%) are immature sandstone, characterized by well-compacted, moderately sorted, fine- to medium-grained, sub-angular to very angular grains (Figs. 5 and 6; Table 1). Composition and texture of these sandstones (Table 1) are mostly similar to those sediments belonging to plagioclase-rich feldspatholithic suites formed in depositional basins associated with volcanic arc orogens (Valloni and Mezzadri, 1984) (Fig. 5). For this reason, they are herein presented as belonging to a single group, which thus includes samples from both sculptures and outcrops. Samples that cannot be clearly assigned to this feldspatholithic suite are presented separately.

\subsubsection{Sandstones belonging to the feldspatholithic suite}

These sandstones are characterized by considerable but distinctive compositional variation. Overall, feldspars and lithic fragments typically predominate over quartz, while lithic fragments are typically volcanic in origin.

Within the studied samples group the total quartz content $(Q)$ varies from 8.7 to $50 \%$ of the framework grains, and averages $19.6 \%$. Samples from Kratie and Preah Khan of Kompong Svay are among the most quartz-rich. The majority of quartz is present as coarse, angular monocrystalline grains with nonundulatory extinction (51\% of the total quartz fraction). Less abundant are undulatory monocrystalline quartz (29\%) and polycrystalline quartz (19\%).

Feldspar grains averages $43.6 \%$ of the total framework and are present as untwinned varieties (80\%) and polysynthetic twinned feldspar (20\%). Sodium-plagioclase prevails over calciumplagioclase and alkali feldspar. Characteristic of the suite are albitized and altered plagioclase grains (Fig. 6).

Lithic fragment contents vary widely within the suite, from lithic-poor (4.5\%) to lithic-rich (61.4\%), with an average of $36.7 \%$. The latter represent the majority of the studied samples, and the specific lithic assemblage includes prevalent igneous and subordinate metamorphic and sedimentary rocks (Fig. 5).
Igneous lithic fragments are dominated by plagioclase- and hornblende-phyric, microlithic volcanic lithic fragments (Fig. 6). Volcanic lithic fragments $\left(L_{\mathrm{V}}\right)$ average $79.6 \%$, but in most samples exceed $80 \%$ of the total lithic fraction (Fig. 5). Often, volcanic lithic fragments are weathered and replaced by authigenic minerals, such as chlorite and calcite. Rare fragments of plutonic rock, consisting of aggregates of quartz and feldspar, are also present.

Metamorphic lithic fragments $\left(L_{\mathrm{m}}\right)$ are generally subordinate to volcanic and average $13.8 \%$. Their relative abundance increases up to $79.5 \%$ only in the volcanic lithic-poor sandstones of the suite, in particular in the areas of Kratie and Preah Khan of Kompong Svay. These grains include fragments of low-grade metamorphic rocks, mainly phyllite and dark chlorite schist, rare quartz-mica schist and fine-grained, strained quartzite.

The content of sedimentary lithic fragments $\left(L_{s}\right)$ averages $6.6 \%$. These grains consist of laminated shale, mudstone and rare siltstone. Carbonate lithic fragments, including ooids and coarse intraclasts, are very rare, but abundant in one sample only (DCA13). Fossiliferous skeletal grains are absent except in sample DCA13.

Relatively large (centimetric to decimetric) fragments of dark, angular sedimentary lithic fragments are occasionally present, and clearly visible at the macroscopic scale suspended in the fine- to medium-grained sandstone. Such occurrences, combined with the absence of clear sedimentary structures and the poor sorting, suggest that the sandstone originated from a high-density turbidity current deposit.

The heavy-mineral $(\mathrm{Ht})$ content averages 5.8\%. The most abundant and characteristic accessory mineral is calcic amphibole with strong green and brown pleochroism, often present in euhedral grains (Fig. 6).

Other accessory minerals include epidote, apatite, titanite, garnet, augite and rare zircon in variable relative amounts. Micas are also present (1\%), with biotite prevailing over muscovite.

Authigenic chlorite and, to a lesser extent calcite, typically replace grains and fine-grained matrix, and constitute the main cement. Heterogeneous chloritization is responsible for the characteristic mottled appearance of the sandstone surface (Fig. 7). In few cases, syntaxial feldspar overgrowth partially cements the 


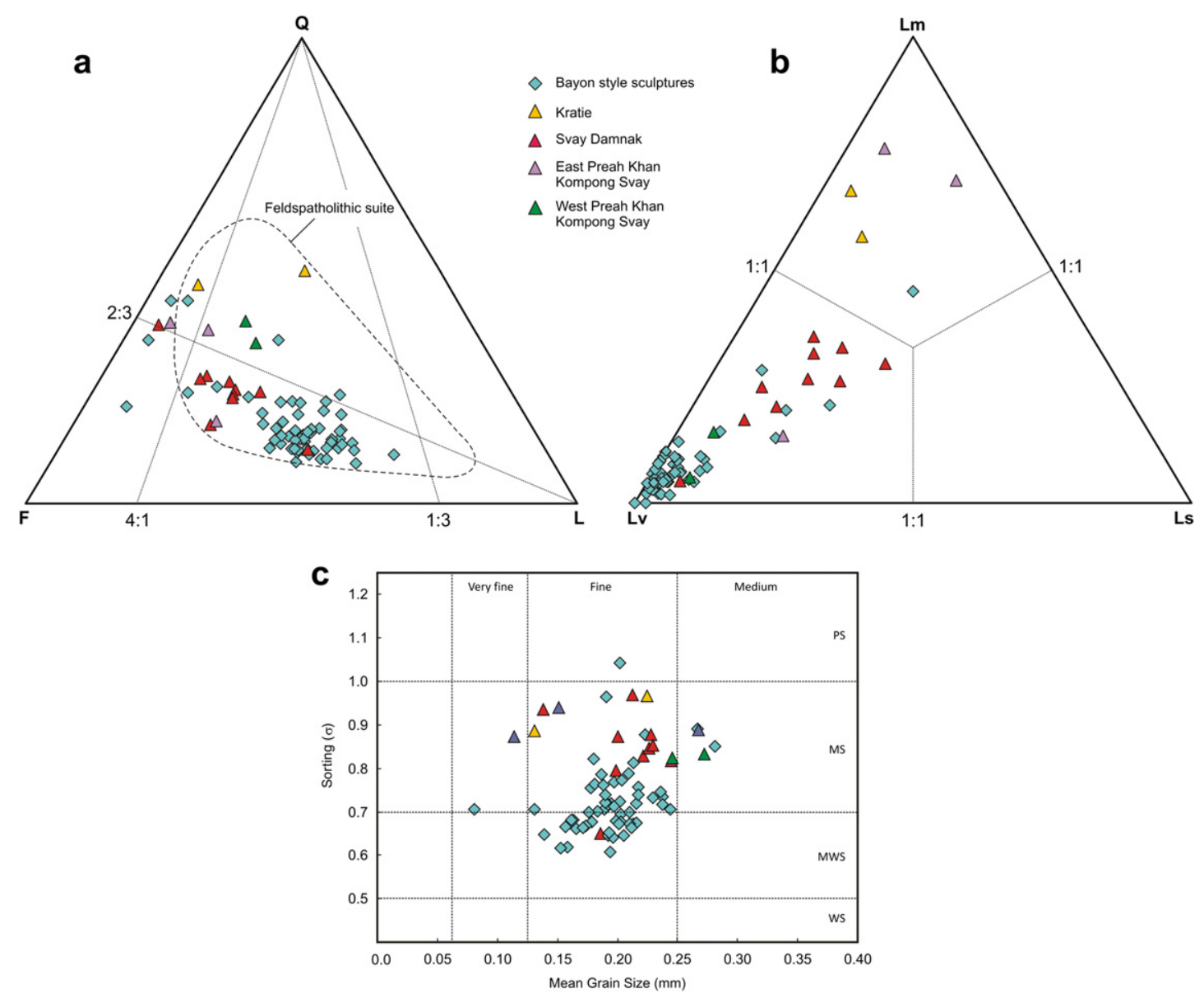

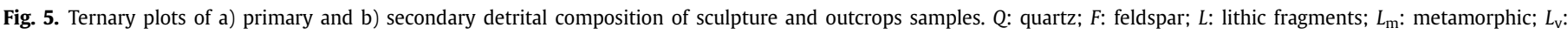

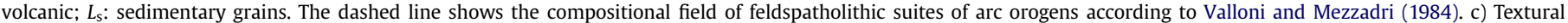
classification of the studied samples. WS: well sorted; MWS: moderately well sorted; MS: moderately sorted; PS: poorly sorted.

framework grains. Secondary epidote is often present at grain boundaries and replaces feldspar grains, likely as a product of diagenesis and and/or hydrothermal alteration (Franz and Liebscher, 2004).

The fine-grained matrix consists of chlorite, sericite, quartz and plagioclase laths and averages $9.6 \%$ of the total sandstone volume. In some cases, nodules of clay-rich matrix are present among the framework grains.

The texture, as seen in thin section, is quite homogeneous; particularly in $L_{V}$-rich sandstones (Fig. 5; Table 1). The mean grainsize ranges from 0.13 to $0.28 \mathrm{~mm}$ (fine-grained), while sorting is generally moderate $(\sigma=0.7)$, if we exclude the rare large clasts.

\subsubsection{Compositional analysis of amphibole grains}

Amphibole group minerals can occur in a fairly complex range in compositions, and are sensitive to the overall chemical environment that prevailed during their formation in an igneous melt, such as pressure, temperature, and the bulk composition of the overall system. For this reason, when a source rock that contains amphibole is disaggregated and its minerals separated from one another, amphibole compositions can help establish whether the population of individual grains originated from a similar geological source.

Earlier research utilizing electron microprobe analysis (EMPA) on amphibole grains present in thin sections of sandstone from Bayon sculptures established this trend (Douglas and Sorensen, 2007). For this reason, a pilot group of a minimum of ten amphibole grains in each of eight thin sections, four field samples from the area of Svay Damnak and four sculpture samples, was analyzed with EMPA for quantitative elemental composition to determine whether this trend holds. Similarly to the earlier studies, all of these amphibole grains can be further divided into two main compositional groups of calcic amphiboles; one within the edenitemagnesiohastingsite (or pargasite) solid solution series, and the other within magnesiohornblende-tschermakite solid solution series (Fig. 8) (for terminology see: Leake et al., 1997). The compositional similarities in the amphibole data in the quarry and sculpture samples support the hypothesis of the same broad igneous source provided the amphibole detritus for these sandstones.

\subsubsection{Sandstones inconsistent with the feldspatholithic suite}

Besides the sandstones that can be ascribed to the plagioclaserich feldspatholithic suite, two other lithotypes, characterized by a more developed textural and mineralogical maturity, have been recognized among the studied samples.

One lithotype is a feldspathic arenite of composition $Q_{44} F_{49} L_{7}$ used for the male bust DCA8. This sandstone is composed of moderately well sorted ( $\sigma=0.6$ ), sub-angular to rounded, finegrained framework grains (mean grain size $=0.14 \mathrm{~mm}$ ) cemented by authigenic chlorite. Quartz and feldspar constitute the majority of the framework grains. Monocrystalline nonundulatory quartz grains (26.2\%) prevail over undulatory (12.2\%) and polycrystalline quartz (5.2\%). Feldspars include prevalent plagioclase and minor alkali feldspar. Lithic fragments are subordinate (7.7\%), and consist, 

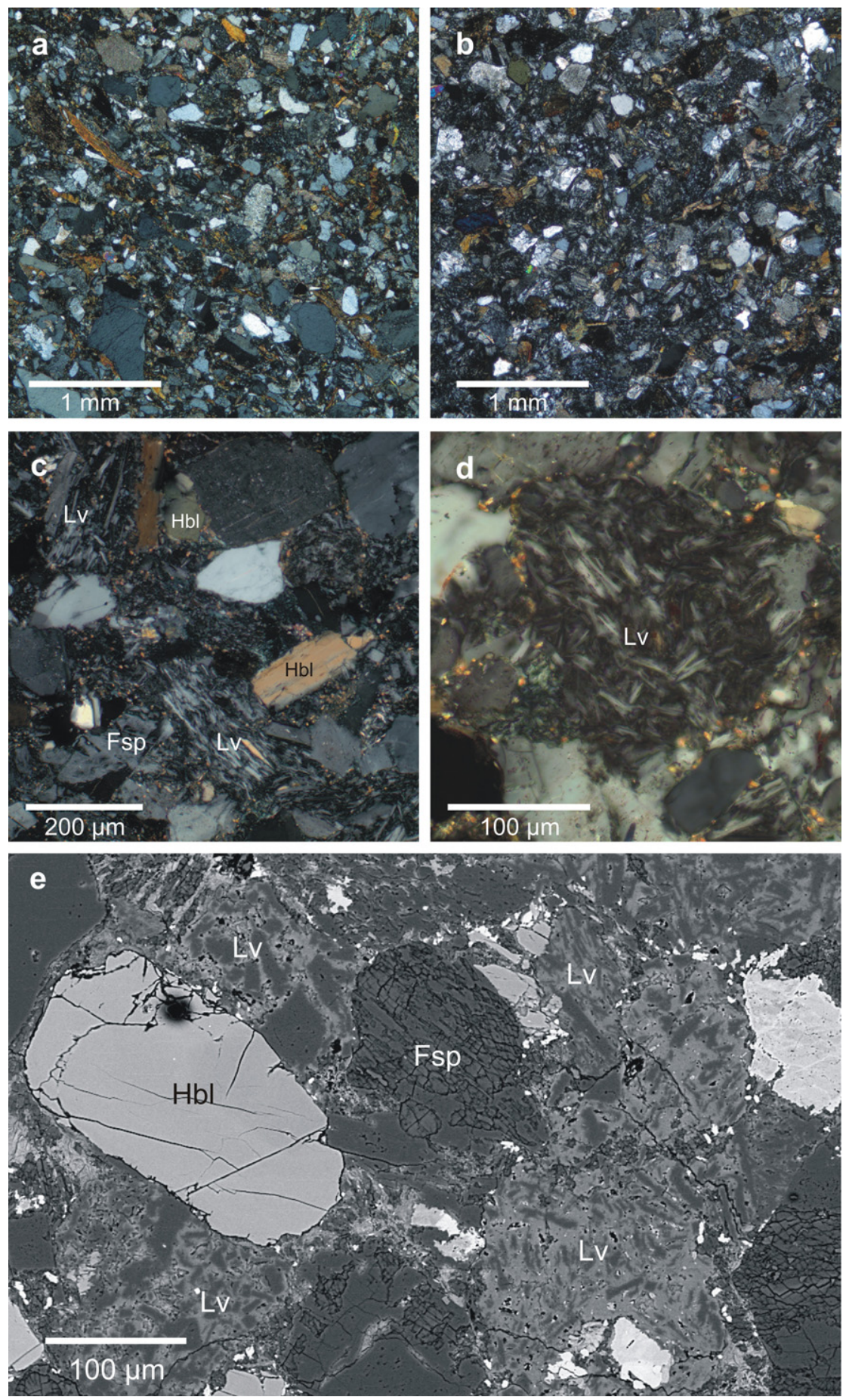

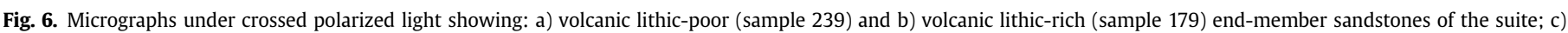

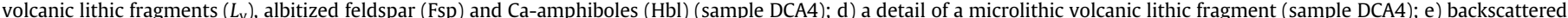
electron (BSE) image of the characteristic grains found in the volcanic lithic-rich sandstone of the suite (Sample DCA26) and abundantly used for Bayon style sculptures.

in order of abundance, of small, intensely-altered andesite grains, low-grade metamorphic phyllite, and fragments of argillite and shale. Accessory minerals include micas $(1.1 \%)$ and heavy minerals such as garnet, epidote, ilmenite, titanite, zircon and apatite (5.9\%). Occasional fine grains of hematite and rutile are also present.

A second lithotype has been identified in the standing female DCA41. This sandstone is a feldspathic arenite characterized by a very fine-grained (mean grain size $=0.08 \mathrm{~mm} ; \sigma=0.7$ ), feldsparrich framework assemblage of composition $Q_{21} F_{71} L_{8}$. Framework grains are well laminated and cemented by authigenic chlorite. Monocrystalline (16.5\%) and polycrystalline (4.3\%) quartz are subordinate to angular to sub-rounded grains of turbid feldspar (64.3\%). Rare plagioclase grains with polysynthetic twinning are also present as well as larger zoned feldspar grains. The lithic fraction is poorly represented by small volcanic microlithic and low-grade metamorphic lithic fragments. Heavy minerals are scarce $(2.5 \%)$ and include predominantly fine-grained iron and titanium oxides, as well as small grains of zircon and epidote. Small 

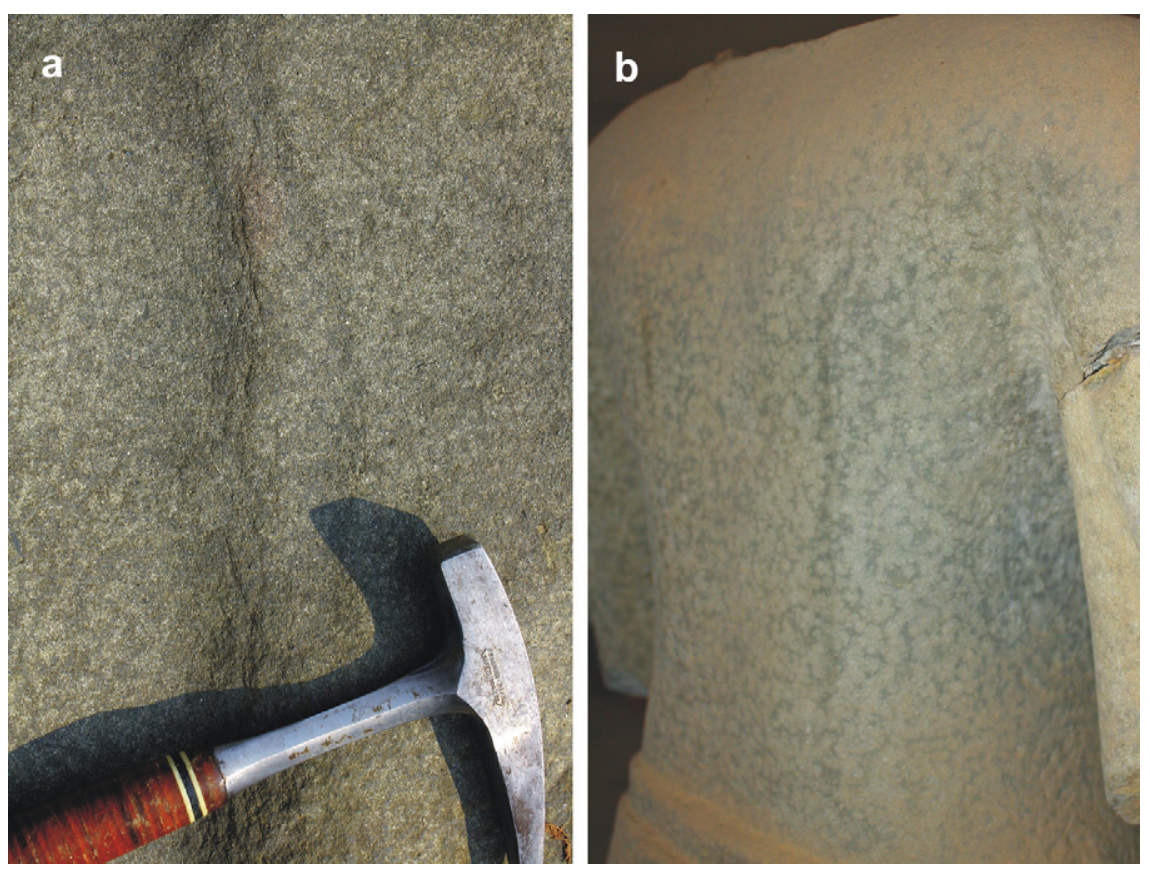

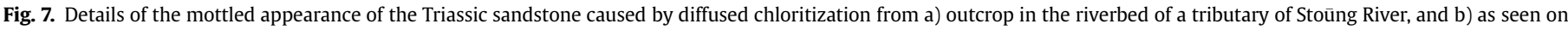
the standing male 6770/253 (sample DCA29), Dépôt de la Conservation d'Angkor.

mica flakes, usually bent between the framework grains, average $0.8 \%$.

\section{Discussion}

\subsection{Sculpture samples}

Petrographic analysis of the Bayon style sculptures studied here suggests that the majority (95\%) are carved from sandstone belonging to the same feldspatholithic suite which comprises the Triassic formation. The sandstone of the sculptures varies from lithic-poor $\left(L=4.6 \% ; L_{\mathrm{V}}=27.3 \%\right)$ to lithic-rich $(L=61.4 \%$; $\left.L_{\mathrm{V}}=94.3 \%\right)$.

Most, however, are markedly lithovolcanic (86\%), i.e. are quartzpoor $(Q<25 \%)$ and extremely rich in microlithic andesite fragments $\left(L_{\mathrm{v}}>83 \%\right)$, albitized feldspar, and hornblende grains. The average composition of this latter distinct sandstone type is $Q_{17} F_{42} L_{41}$.

If compared to the overall suite's broad compositional variation $\left(L_{\mathrm{V}}=7-100 \%\right)$, the narrow composition variation $\left(L_{\mathrm{V}}=83-100 \%\right)$ of most of the sculptural stone is indicative of a localized source, possibly a single quarry district within the Triassic formation.

Few of the studied sculptures are realized from lithic-poor sandstone belonging to the same Triassic feldspatholithic suite. Among them, the Buddha sheltered by Naga of unknown provenance, DCA12, the Lokeśvara head found at Tep Pranam in Angkor Thom NMC990, the stele from Prasat Preah Khan DCA17, the standing female from Ta Nei DCA38 and the Vishnu head from Angkor Wat NMC2995. These sandstones contain more quartz ( $Q=24-44 \%)$ and fewer lithic fragments ( $4.5<L<28.2 \%)$, and have a higher content of lithic fragments of metamorphic origin $\left(L_{\mathrm{m}}=24 \%\right)$ than the sandstone commonly used for Bayon style sculptures.

The standing Vishnu from Kok Prei, DCA13, is carved from a distinctive carbonate-rich, immature sandstone characterized by abundant limestone mudrock fragments, calcareous fossil fragments, ooids, abundant calcite matrix and cement. This sandstone contains also andesite lithic fragments, albitized feldspars, and hornblende grains typical of sandstones of the majority of Bayon style sculptures in this study. This finding suggests this rock type may be a calcareous member of the feldspatholithic suite of the Triassic formation.

Finally, two sculptures are made with sandstones that do not belong to the Triassic formation. The male bust from Ta Prohm, DCA8, is carved from a fine grained (mean grain size $=0.14 \mathrm{~mm}$ ) feldspathic arenite of composition $Q_{44} F_{49} L_{7}$ that, for compositional and textural characteristics, can be attributed to the Lower-Middle Jurassic Terrain Rouge Formation (Carò and Im, 2012). Another sculpture, a small standing female DCA41 from Prasat Kuk Snuol, is carved from a very fine-grained feldspathic arenite which is extremely rich in feldspar grains $\left(Q_{21} F_{71} L_{8}\right)$. Interestingly, this stone has strong similarities to sculptures carved in Angkor Wat and Baphuon style (unpublished data by the authors) dating from the 2 nd half of the 11th century to the 1 st half of the 12 th century. Currently the provenance of this stone is unknown.

\subsection{Field samples}

In the surveyed areas, sandstone outcrops show petrographic and textural characteristics compatible with the Triassic formation described in literature (Contri, 1972). The distinctive characteristics of this feldspatholithic sandstone are 1) immature texture of subangular to angular, moderately sorted, and fine grain-size; 2) the variable but ubiquitous presence of plagioclase and hornblendephyric, microlithic volcanic lithic fragments $\left.\left(L_{\mathrm{V}}\right) ; 3\right)$ hornblende grains and albitized plagioclase grains; and 4) diffuse authigenic chlorite.

Near the village of Svay Damnak, where our sampling campaign was denser, the compositional variation characterizing this suite is demonstrated. Here, the sandstone changes from lithic-poor ( $\left.L=4.8 \% ; L_{\mathrm{V}}=40 \%\right)$ to lithic-rich $\left(L=45.3 \% ; L_{\mathrm{V}}=89.5 \%\right)$ within an area of about $1 \mathrm{~km}^{2}$. Lithic-rich sandstones are also particularly rich in volcanic lithic fragments. 


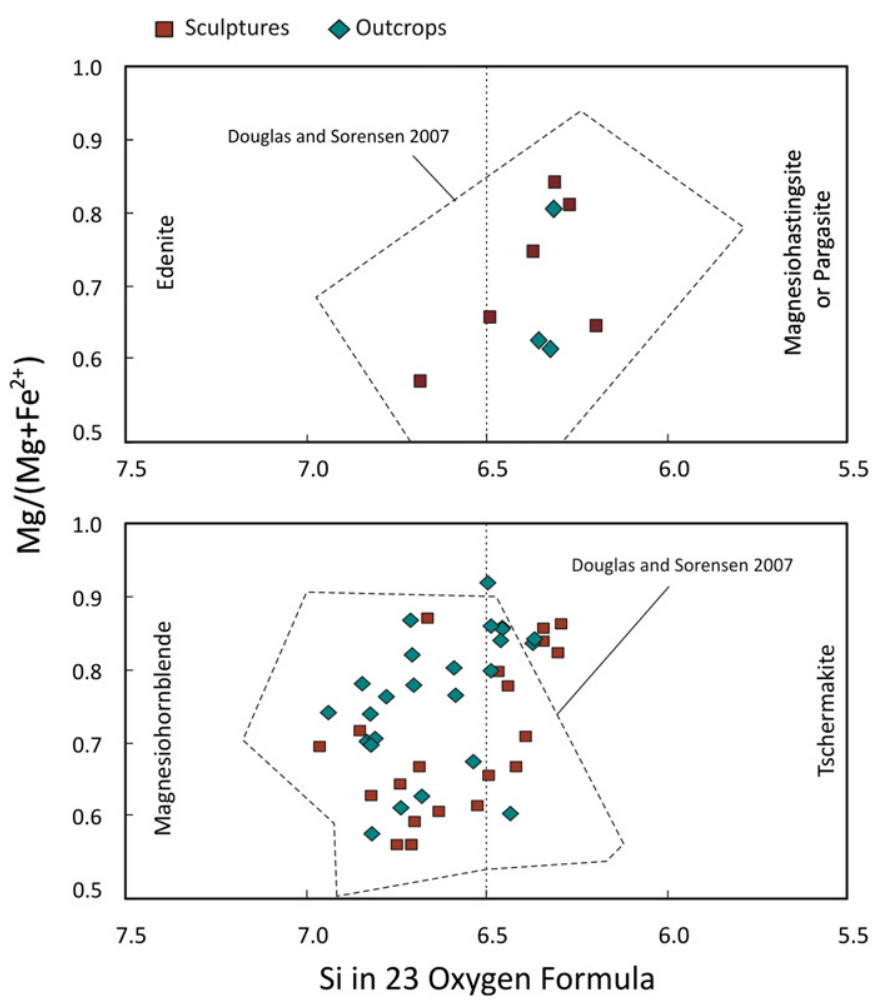

Fig. 8. Amphibole microprobe data of sculpture and field samples compared to Douglas and Sorensen (2007).

Evidence of quarrying activity exists in Kratie province (Bruguier, 2006), while traces have been discovered in the area of Svay Damnak, where further work is needed to determine the extent of their occurrence.

Remains of wedge holes and splitting channels indicate that the sandstone was quarried and sized locally, although currently their date is unknown. Also, these remains alone cannot account for the vast Bayon style sculptural production (Cœdès, 1958; Stern, 1965; Jessup and Zephir, 1997), and further archaeological studies are needed in the area to assess the real extension of the site.

The sandstone from Kratie province and from the surroundings of Preah Khan of Kompong Svay is characterized by higher quartz content $(Q=33.6 \%)$ and lower lithic fragments $(L=18.2 \%)$, and can be ascribed to the lithic-poor end member of the series. In Kratie, lithic fragments of metamorphic origin predominate over volcanic and sedimentary ones, while around Preah Khan of Kompong Svay the lithic assemblage varies from volcanic-poor $\left(L_{\mathrm{V}}=7.7 \%\right)$ to volcanic-rich $\left(L_{\mathrm{V}}=87.5 \%\right)$.

The traces of exploitation found in Svay Damnak, as well as others that have been discovered to date, are not sufficient to confirm the presence of a developed and organized site of stone extraction, nor the presence of stone workshops in this area. No dressed blocks or unfinished sculptures have been found around Svay Damnak and Preah Khan Kompong Svay. Conversely, dressed blocks and unfinished pedestals are still lying in the sites along the Mekong River north of Kratie.

Field observations revealed that Triassic sandstones are exposed in scattered outcrops of small surface extension and height. Outcrops along and in riverbeds are usually the most extensive (Fig. 4b). The traces of stone exploitation were found in the vicinity of riverbeds, and suggest that boulders were split close to their original location. The practice of splitting and dressing existing boulders can be justified by the presence of a diffuse system of almost orthogonal joints that separates the massive sandstone into defined blocks. This characteristic is particularly intense towards Preah Khan of Kompong Svay, but has been observed in all the surveyed sites included in several outcrops in Kratie province. Severe stone weathering and abundant loose sediment cover may be contributing to conceal further quarry remains. For these reasons, clear and organized traces of sandstone quarries, such as the stepped surfaces found at the foothill of Kulen Mountain in the Terrain Rouge formation (Carò and Im, 2012), may be difficult to find.

\section{Conclusion}

Based on current geological knowledge of Cambodia, the Triassic formation was chosen for survey as the potential source of sandstone for the production of Bayon style sculpture during the reign of Jayavarman VII. Results from petrographic analysis of field samples show that the Triassic formation is characterized by sandstone of considerable compositional and textural variations.

The study of the large corpus of Bayon style sculptures reveals that the stone used for the majority of the objects belongs to the same Triassic formation that is exposed in the surveyed area. Moreover, the narrow compositional variation of the sculptural sandstone found here and in previous study (Douglas and Sorensen, 2007) strengthens the hypothesis that a localized source of stone was exploited for the production of royal sculptures under Jayavarman VII's reign.

Sandstone of similar texture and composition is exposed in the vicinity of Svay Damnak, a village located about $16 \mathrm{~km}$ southeast of Preah Khan Kompong Svay. Remains of quarrying activity in the form of wedging and splitting channels further support the idea that sandstone may have been quarried from this area during Jayavarman VII's reign. The recovery of unfinished sculptures or dressed blocks and other archaeological remains will be essential in the final identification of the royal quarries that provided the majority of the stone used during Jayavarman VII's reign for sculptures of Bayon style. Hopefully the current work can induce further archaeological studies in the area where the Triassic formation occurs.

Although the vast majority of sculptures have been identified as composed of sandstone from the Triassic formation, two sculptures are carved from stone unlike the sandstone of the Triassic formation. This finding suggests that other, albeit minor, geological sources and sculpture workshops existed during the reign of Jayavarman VII. As more sculptures are studied and archaeological research progresses, we can develop a more thorough understanding of Khmer sculpture production from quarrying at the geological source, to carving at the stone workshop, to final installation within a temple.

\section{Acknowledgments}

The research was supported through a Forbes fellowship at the Freer Gallery of Art, Smithsonian Institution in 2011, and an Andrew W. Mellon fellowship at The Metropolitan Museum of Art in 2010. This work could not have been accomplished without the support and help of several people and institutions. The authors are particularly grateful to: H.E. Chuch Phoeurn, Secretary of State, Ministry of Culture and Fine Arts, Cambodia; H.E. Yang Chantha, Department of Safeguarding and Preservation of Monuments, Ministry of Culture and Fine Arts, Cambodia; H.E. Hab Touch, former director of the National Museum of Cambodia; Bertrand Porte, stone conservator, École Française d'Extrême-Orient (EFEO) working at the National Museum of Cambodia; Im Sokrithy, Ea Darith and Kim Sreung, Authority for the Protection and Management of Angkor and the Region of Siem Reap (APSARA); Dominique 
Soutif, Head, École Française d'Extrême-Orient (EFEO) Angkor, Siem Reap; Karin Schinken and Elke Tigges, Conservators, Deutsche Gesellschaft für Internationale Zusammenarbeit (GIZ) in Siem Reap; Eric Breitung, Senior Scientist at the Library of Congress, Washington DC; Tim Rose, Manager of Analytical Laboratories, Department of Mineral Sciences, Smithsonian Museum of Natural History; and Paul A. Lavy, Assistant Professor of South and Southeast Asian Art, University of Hawai'i, Honololu.

\section{References}

Alabouvette, B., 1973. Carte Geologique de Reconnaissance 1/200000, Stung Treng. Service National des Mines de la Geologie et du Petrole. Editions du Bureau de Recherches Geologiques et Minieres.

Bruguier, B., 2006. Carte Archéologique du Cambodge - Bassin du Mekong. Ministère de la Culture et des Beaux-Arts - École française d'Extrême-Orient.

Carling, A.P., 2009. The geology of the lower Mekong River. In: Campbell, Ian C. (Ed.), The Mekong: Biophysical Environment of an International River Basin. Academic Press, pp. 13-28.

Carò, F., Im, S., 2012. Khmer sandstone quarries of Kulen Mountain and Koh Ker: a petrographic and geochemical study. Journal of Archaeological Science 39 (5), $1455-1466$.

Carò, F., 2009. Khmer stone sculptures: a collection seen from a material point of view. The Metropolitan Museum of Art Bulletin, Summer 200967 (1), 26-32.

Carter, A., Roques, D., Bristow, C., Kinny, P., 2001. Understanding Mesozoic accretion in Southeast Asia: significance of Triassic thermotectonism (Indosinian orogeny) in Vietnam. Geology 29 (3), 211-214.

Cœdès, G., 1958. Les statues du roi khmèr Jayavarman VII. In: Comptes-rendus des séances de l année - Académie des inscriptions et belles-lettres, vol. 3, pp. 218-226.

Contri, J.P., 1972. Carte Geologique de Reconnaissance 1/200000, Tbeng-Meanchey. Service National des Mines de la Geologie et du Petrole. Editions du Bureau de Recherches Geologiques et Minieres.

Delvert, J., 1963. Recherches sur l'erosion des grès des monuments d'Angkor. Bulletin de l'École Française d'Extrême-Orient 51 (2), 453-534.

Demeter, F., Patole-Edoumba, F., Duringer, P., Bacon, A.M., Sytha, P., Bano, M., Laychour, V., Cheangleng, M., Sari, V., 2010. Reinterpretation of an archaeological pebble culture from the Middle Mekong River Valley, Cambodia. Geoarchaeology: An International Journal 25 (1), 75-95.

Douglas, J.G., Sorensen, S., 2007. Mineralogical characteristics of Khmer stone sculpture in the Bayon style. In: Douglas, J.G., Jett, Paul, Winter, John (Eds.) Scientific Research on the Sculptural Arts of Asia, Proceedings of the Third Forbes Symposium at the Freer Gallery of Art. Archetype Publications in Association with the Freer Gallery of Art, Smithsonian Institution, Washington, pp. 115-124.
Douglas, J.G., Carò, F., Fisher, C., 2010. Evidence of sandstone usage for sculpture during the Khmer empire in Cambodia through petrographic analysis. UDAYA Journal of Khmer Studies 9, 1-17.

Fleuriot de Langle, P., 1973. Carte Geologique de Reconnaissance 1/200000, Mondulkiri. Service National des Mines de la Geologie et du Petrole. Editions du Bureau de Recherches Geologiques et Minieres.

Franz, G., Liebscher, A., 2004. Physical and chemical properties of the epidote minerals. An Introduction. Reviews in Mineralogy and Geochemistry 56, 1-82.

Jacques, C., 2007. The historical development of Khmer culture from the death of Sūryavatman II to the 16th century. In: Clark, J. (Ed.), Bayon - New Perspectives. River Books, pp. 30-49.

Jarosewich, E., Nelen, J.A., Norberg, J.A., 1980. Reference samples for electron microprobe analysis. Geostandards Newsletter 4, 43-47.

Jessup, H.I., Zephir, T., 1997. Sculpture of Angkor and Ancient Cambodia. Thames and Hudson.

Kučera, J., Novák, J.K., Kranda, K., Poncar, J., Krausová, I., Soukal, L., Cunin, O., Lang, M., 2008. INAA and petrological study of sandstones from the Angkor monuments. Journal of Radioanalytical and Nuclear Chemistry 278, 229-306.

Leake, B.E., Woolley, A.R., Arps, C.E.S., Birch, W.D., Gilbert, M.C., Grice, J.D. Hawthorne, F.C., 1997. Nomenclature of amphiboles: report of the subcommittee on amphiboles of the international mineralogical association, commission on new minerals and mineral names. American Mineralogist 82 (9/10), 1019-1037.

Metcalfe, I., 1994. Gondwanaland origin, dispersion, and accretion of East and Southeast Asian continental terranes. Journal of South American Earth Sciences 7 (3/4), 333-347.

Racey, A., Love, M.A., Canham, A.C., Goodall, J.G.S., Polachan, S., Jones, P.D., 1996 Stratigraphy and reservoir potential of the Mesozoic Khorat Group, NE Thailand. Journal of Petroleum Geology 19 (1), 5-40.

Sotham, S., 1997. Geology of Cambodia. Coordinating Committee for GeoScience Programs in East and Southeast Asia Technical Bulletin 26, 13-23.

Stern, P., 1965. Les monuments Khmers du style du Bayon et Jayavarman VII. In: Publications du Musée Guimet, Rcherches et Documents d'Art et d'Archéologie, vol. IX. Presses Universitaires de France, Paris.

Uchida, E., Cunin, O., Suda, C., Ueno, A., Nakagawa, T., 2007. Consideration on the construction process and the sandstone quarries during the Angkor period based on the magnetic susceptibility. Journal of Archaeological Science 34, 927-935.

United Nations, 1993. Economic and Social Commission for Asia and the Pacific Atlas of Mineral Resources of the Escap Region. In: Cambodia, Explanatory Brochure, vol 10. United Nation, New York.

Valloni, R., Mezzadri, G., 1984. Compositional suites of terrigenous deep-sea sands of the present continental margins. Sedimentology 31, 353-364.

Woodward, H.W., 1980. Some Buddha images and the cultural developments of the late angkorian period. Artibus Asiae 42 (2/3), 155-174.

Woodward, H.W., 1994/95. The Jayabuddhamahānātha images of Cambodia. Journal of the Walters Art Gallery 52 (5), 105-111. 